\title{
More than just the Adoption of Western Capitalism? Time Use Changes in East Germany Following Reunification
}

\author{
Otto Lenhart ${ }^{1,2}$ (D)
}

Published online: 26 April 2018

(C) The Author(s) 2018

\begin{abstract}
Using data from the German Socio-Economic Panel, this paper examines changes in East German time use following the German Reunification of 1990, which led to large and unexpected economic and institutional changes, including the switch from a socialist to a capitalist system. By estimating Differences-in-Differences models, the study finds that East Germans reduced the time they spend on market work (96 min per weekday) and nonmarket work (51 min), while increasing the time allocated toward leisure and job search activities. The observed declines in market work time were largest for low-educated East Germans, those who were in the lowest income group, as well as for individuals between the ages 46 and 64 . When comparing trends in time use for East and West Germany between 1990 and 2000, I provide evidence for a convergence in East German time use to its West German counterpart following the adoption of Western Capitalism and several other institutional and economic changes in East Germany. One possible explanation for this might be the adoption of West German time preferences following the reunion of the two regions.
\end{abstract}

Keywords German Reunification · Time use · Transition · GSOEP

JEL Classification $\mathrm{J} 22 \cdot \mathrm{J} 64 \cdot \mathrm{P} 10 \cdot \mathrm{P} 20$

Otto Lenhart

olenhart@uwf.edu

1 Department of Marketing and Economics, University of West Florida, 11000 University Pkwy., Building 53, Pensacola, FL 32514, USA

2 Department of Economics Strathclyde Business School, University of Strathclyde, 199 Cathedral Street, Glasgow G4 0QU, UK 


\section{Introduction}

The year of 1990 brought dramatic changes to the lives of people in East Germany as the reunion of East and West included a rapid switchover from socialism to capitalism, coupled with significant institutional and economic changes. German Reunification included not only an economic union, but also monetary and social unions. East Germans were suddenly confronted with a new economic system, a new currency and a moredeveloped social welfare system compared to before 1990. Incomes of East German workers increased after reunification following the adoption of West German labor unions, while Easy Germany also received substantial public sector transfer payments from West Germany. Approximately $20 \%$ of these transfers went to support labor market policies in the form of unemployment insurance (Hall and Ludwig 1994). On the downside, however, due to the significant differences in productivity between East and West Germany before and after 1990, the sudden adoption of West German markets led to a large growth of unemployment rates in the former German Democratic Republic (GDR). Since people in East Germany did not anticipate the dramatic changes that they were confronted with, German Reunification offers a setting close to a "natural" experiment. This study uses these arguably exogenous changes to the lives of East Germans to examine the effects of institutional and economic changes on time allocation.

By using data from the German Socio-Economic Panel (GSOEP), this study addresses two research questions: 1) By using Differences-in-Differences (DD) models and recall survey responses for the years 1990 to 1992, I test how reunification impacted the time that East Germans allocate towards categories, such as market work, nonmarket work, education, childcare, and leisure. 2) By examining general trends in time allocation for East and West Germany between 1990 and 2000, I explore whether the adoption of Western ideologies led to a convergence in time use between the two German regions. This part of the analysis differentiates between changes in time use due to job loss (internal effects) and changes that are driven by the environment and by potential adoptions of the West German culture (external effects).

This study contributes to the existing literature on time use in several ways. First, given the magnitude of economic, institutional and social changes, which include a shift from socialism to capitalism, an examination of the impacts of German Reunification on time allocation guarantees that all individuals in the sample were directly affected by the changes. Second, by differentiating between internal and external effects of reunification on time use, the study is able to provide evidence on whether social and cultural adoptions of Western lifestyles occurred shortly after the large changes to the system in East Germany in 1990. Thus, the study provides suggestive evidence for welfare effects of German Reunification by showing how it affected time spent on work and on other activities (e.g. leisure) not only due to job loss but also due to environmental or cultural changes that occurred immediately after reunification. Third, by including data on time use in West Germany at the time, the study is able to check whether reunification and the adoption of the Western ideology of Capitalism in East Germany led to a convergence in time use between the two regions.

The analysis finds a substantial decline in daily work time of 96 min per day for East Germans shortly after reunification. In contrast to findings from the Great Recession by Aguiar et al. (2013), my analysis shows that East Germans also reduce the time they spend on nonmarket work activities, such as housework, gardening, or errands, as well as on childcare. 
The study suggests that East Germans reallocate time from these activities toward additional leisure time after 1990. The observed declines in market work time were largest for loweducated East Germans, those who were in the lowest income group, as well as for individuals between the ages 46 and 64. When examining trends in time use for both German regions in the decade after reunification, I find evidence for a convergence of East German time allocation to West German levels. While the declines in market work for East Germans are mainly driven by changes in employment, the study also provides evidence for time use changes due to other outside factors (e.g. exposure to a new environment and culture).

\section{Previous Literature}

Becker (1965) provided the first general theory of how we should think about allocation of time across different activities, which laid the foundations for the study of household production and the allocation of time within the household. Ghez and Becker (1975) highlighted the importance of examining the substitutability between time spent on market and nonmarket work in order to understand work labor supply decisions over the life cycle. Both these studies set the framework for several time use studies over the past decades. To my knowledge, this is the first study that specifically tests for the effects of large institutional changes on the allocation of time.

Using data from the American Time Use Survey (ATUS), Aguiar et al. (2013) examine changes in time allocation during the Great Recession in the US. The authors show that aggregate market work hours in the US fell by $7 \%$ during the Great Recession and provide evidence that about three-fourth of this decline is due to changes on the extensive margin of employment. When investigating how individuals reallocated their time away from market work, Aguiar et al. (2013) find that roughly $50 \%$ of the lost working hours is reallocated toward additional leisure time, $30 \%$ is reallocated toward nonmarket work activities, $12 \%$ toward personal health care, education and civic activities, and 5\% toward childcare. In a related study, Kawaguchi et al. (2013) examine changes in time allocation as a response to exogenous cuts in standard work hours in Japan and Korea, which were mandated by the government. The authors find that individuals use the additional time for more leisure and, to a lesser extent, for more household production. While examining changes in time allocation following institutional and economic changes rather than during a recession, this study uses the same time use categories as Aguiar et al. (2013).

Previous work in the time use literature has provided evidence for a negative association between housework and wages in the US (Hersch 2009; Kimmel and Connelly 2007). A potential concern for these results is that they cannot rule out that higher wages lead to less time allocated to housework due to the substitution effect dominating the income effect, or if individuals shifts from own to paid housekeeping. German Reunification not only led to significant institutional and economic changes, the adoption of the Western market also affected earning of workers. Burda and Hunt (2001) suggest that $81 \%$ of East Germans experienced a wage raise following the dramatic changes to the economy in 1990. Hunt (2001) shows that the median real monthly wage of workers between the ages 18 to 54 increased by $83 \%$ between 1990 and 1996. Thus, examining changes in time use in East Germany after reunification can contribute to previous work on the effects of wages on time allocation. 


\section{Background on the German Reunification}

After World War II, the East German region was occupied by Soviet forces, which then formed the German Democratic Republic (GDR) in 1949. The GDR placed emphasis on having its own identity and did so by having an own government and currency. While the American, British and French zones created a capitalist nation in 1949 in the West, the German Federal Republic, the GDR became a socialist state. Following the collapse of the Soviet Union and the one-party rule in East Germany 1989, the signing of a Unification Treaty by East and West German Government on August 31, 1990 brought upon the end of a divided Germany.

Through the falling of the Berlin Wall, individuals living in the East were now allowed to enter West Germany legally. In order to improve existing labor market conditions to bring them closer to the West German level as well as to prevent mass migration movements of qualified workers to the West, wages were increased significantly in East Germany immediately after the reunion. Furthermore, wages and working conditions were improved through the adoption of Western style labor unions. However, the differences in the states of the West and East German economies proved to be too large. During the late 1980s, the East German economy was in a terrible condition having productivity levels that equaled one-third of the West German level. Hall and Ludwig (1994) show that East Germany's productivity was still only at 50\% of the West German level in 1994, indicating that productivity increased at much lower rates compared to wages (Hunt 2001).

Thus, the improvement of economic conditions due to wage increases experienced by many workers in East Germany was offset by large unexpected increases in unemployment rates. While unemployment rates were around $1 \%$ prior to reunification in East Germany, they increased to around 15\% by 1992 (Federal Employment Agency). The adoption of West Germany's well-developed social welfare system provided a safety net to East Germans struggling to integrate into the new economic system (Hall and Ludwig 1994). Additionally, active labor market programs, designed to provide East Germans with training, were implemented to cushion the collapse of the labor market (Burda and Hunt 2001).

Finally, the union of the two German parts also included a monetary union. The currency of the former GDR was immediately replaced by the German Mark, the currency of the West, at a rate of 1:1. At the time of monetary union, earnings in East Germany were about a third of those in West Germany, before reaching three-quarters of western level by 1996 due to the substantial wage increases to workers in the East.

\section{Reunification and Time Use}

The dramatic changes that occurred in East Germany at the time of reunification significantly affected the lives of individuals. This section provides four potential pathways through which reunification could have impacted time use of East Germans. First, time allocation can be affected for individuals who lost their employment immediately after 1990 . Within 1 year of reunification, unemployment rates in East Germany, an area that was previously characterized by almost full employment, increased to almost $10.3 \%$ (Burda and Hunt 2001). Second, the newly adopted social 
welfare system from the West could affect the supply of labor, as suggested by von Hagen and Strauch (1999) and Hunt (2008). The availability of a more generous social assistance program, unemployment insurance, and pensions could provide disincentives for East Germans to work the same number of hours as they did before reunification.

Third, active labor market programs were offered to individuals in East Germany following reunification. Hunt (2008) suggests that take-up rates for public training programs and government-sponsored jobs were high in the early 1990s. However, previous research has provided evidence for potential negative effects of these public initiatives on labor force participation. Lechner et al. (2007) show that the training programs have kept participants out of the labor force for the duration of the 'sometimes long programs', while Hunt (2008) points out that people working in public jobs had no incentive to look for another job since they received $100 \%$ of the union wage. Fourth, increases in wages following reunification could change time allocation due income and substitution effects. On the one hand, individuals might work more and spend less time on other activities due to the increased opportunity costs of non-work time (income effect). On the other hand, individuals might substitute market work hours with more leisure time, for example, since they are earning higher wages and given that there were more consumption goods available following the fall of the Berlin Wall.

The large and unexpected changes that occurred in Germany shortly following reunification could have influenced time use of individuals through internal and external effects. The dramatic increases in unemployment rates could directly impact the allocation of time of households that experienced job loss following reunification (internal effects). Since both German regions experienced increases in unemployment rates in the 1990s, internal effects could have occurred in East and West Germany. However, given that economic changes were substantially larger in East Germany, we might expect differences between the regions.

Besides through internal effects, reunification could also affect time use by changes in the environment or culture that are unrelated to people's employment status may have affected time use (external effects). One example of an external effects is the sudden change from socialism to capitalism in East Germany, leading to the first free elections in the former GDR following four decades of authoritarian rule. In addition, the West German currency, systems of justice, regulation, industrial relations, banking, education, social security and welfare were all transferred to East Germany (Hunt 2008). These changes could have influenced time allocation by increasing uncertainty about the future among people who lived the majority of their lives under the socialist regime. Again, it can be expected that these effects are larger for individuals living in East Germany. Another example of external effects are potential changes in time preferences following the union of the two German countries. Given the differences in the number of work hours per week as well as the different political systems between East and West Germany prior to 1990, one might expect differences in time preferences across the two regions. Wang et al. (2011) provide evidence for differences in time preferences across countries. By analyzing time use in 45 countries, the authors find that countries in Germanic Europe are more future-oriented than countries in Latin Europe. Marti et al. (2017) show that differences in time preferences and cultural background can explain differences in health-related well-being of individuals living 
in the German-speaking part of Switzerland compared to people living in the nearby French-speaking part of the Switzerland. Changes in work effort and productivity in East Germany following the events of 1990 could be another external factor responsible for changes in time use. While East Germans worked longer hours prior to 1990, the productivity levels of the East German economy were around one-third of its West German counterpart during the late 1980s. While these differences can to some extent be explained by institutional settings, higher overall of work efforts by the average West German worker are likely another explanation for the large economic gap. Burda and Hunt (2001) provide evidence that there were dramatic increases in East German labor productivity following German reunification (from $43 \%$ of its West German counterpart in 1991 to $73 \%$ in 2000 ).

While this study is not able to fully disentangle the role of internal and external effects. I indirectly test for the two effects by adding three additional specifications to the analysis by using the longitudinal nature of the data set in a set of additional specifications. First, I stratify the sample by employment status, which allows me to check whether the changes in time use were different across people who lost their job immediately following reunification and those who remained employed. If changes in times use are also observable for individuals that remained employed, this would provide suggestive evidence that external factors, such as environmental or cultural changes following reunification, play a role in explaining the effects on time allocation. Second, I test for differences in the effects between individuals who lost their employment immediately after the reunification in East and West Germany. Given that people in East Germany were confronted by more sudden changes to society, finding differential effects between "job losers" from the two groups can provide further evidence for external effects. Third, I conduct a similar analysis that compares time use changes of individuals who remained employed throughout the study period. Fourth, I separate both the East and West German sample into two groups: 1) states that experienced high increases in unemployment rates following reunification within the region; 2) states that experienced relatively small increases in unemployment rates within the region. These four additional tests can shed light whether internal or external effects of reunification drive any changes in time use in Germany following the events of 1990.

\section{Data}

\section{German Socio-Economic Panel (GSOEP)}

The study uses data from the German Socio-Economic Panel (GSOEP), a nationally representative large sample of individuals that was initiated in 1984 in West Germany (for an overview of the data set, see Haisken-DeNew and Frick 2005). ${ }^{1}$ In 1990, the panel was extended to include residents of the former GDR. Most importantly for the purpose of my analysis, the first wave of the Eastern sample in 1990, which included

\footnotetext{
${ }^{1}$ This study uses the international version of the GSOEP, which includes $95 \%$ of the original sample due to German data protection laws.
} 
6131 individuals from 2179 households, was collected before the reunification in June of that year. The GSOEP questions all people above the age of 15 who live in the household at the time of the interview.

Given that individuals in Germany become eligible for state pension at the age of 65 , the sample is restricted to individuals below the age of 65. People who took early retirements in the first 2 years following reunification were also dropped from the main analysis $(n=252)$. Additionally, I drop individuals with missing time use information $(n=752)$ as well as those who moved between East and West Germany during the sample period 1990 to $1992(n=180)$. This provides my analysis with a sample 25,136 observations for these 3 years. This sample includes 14,808 observations from West Germany and 10,328 observations from East Germany. In additional specifications, I use demographic information (income, employment status, age, gender, and education) provided in the GSOEP to examine changes in time allocations for different groups of the population. ${ }^{2}$

The study uses data for the years 1990 to 1992, which provides several benefits to the analysis as well as contributions to previous studies in the literature. The main question of interest for this study is the following: "What is a typical day like for you? How many hours do you spend on the following activities on a typical weekday?" The survey asks participants to provide information on eight different activities: (1) job, apprenticeship, second job; (2) errands, such as shopping and trips to government agencies; (3) housework, such as washing, cooking, and cleaning; (4) Care and support for persons in need of care; (5) Repairs on and around the house, such as car repairs or garden work; (6) Hobbies and other free-time activities; (7) Education or further training, including school and university; (8) Child care. Consistent with the framework of Aguiar and Hurst (2007) I combine time spent on activities (2) to (5) into one main category called nonmarket work. ${ }^{3}$ Thus, my study tests for the effects of the institutional and economic changes following reunification on five categories of time use: market work (1), nonmarket work (2-5), leisure (6), education (7), and child care (8). Two limitations of the GSOEP compared data set with a focus on time use is that time use information is the use of recall survey questions (rather than detailed diary entries) as well as the fact that time use is rounded up to whole hours.

\section{Descriptive Statistics}

Table 1 presents summary statistics for the sample of 23,430 individuals for the period of the main analysis in this study (1990-1992). The data shows that $37.85 \%$ of respondent live in East Germany, while the sample consists evenly of both males and females. Using data on average state unemployment rates from the Bundesagentur für Arbeit (Federal Employment Agency), Table 1 also shows that state-level unemployment rates increased

\footnotetext{
${ }^{2}$ Despite providing more insight on the heterogeneity of the effects across the population, time use trends for groups separated by income and employment status should be treated with caution since these categories are mechanically linked to market hours of work and thus with time spent outside of market work.

${ }^{3}$ A report by Robinson and Godbey (1999) uses data from the 1985 Time Use Survey to provide evidence on reported levels of enjoyment respondents obtain from certain activities $(10=$ highest, $0=$ lowest). Generally, activities with the highest level of satisfaction are classified as leisure. Work scores a 7.0 on the enjoyment scale, whereas housework scores a 5.8. Activities such as gardening (7.1), pet care (6.0) and yard work (5.0) score significantly lower than leisure activities. Thus, it appears reasonable that these activities should be classified as nonmarket work rather than as leisure.
} 
Table 1 Descriptive statistics

\begin{tabular}{lllll}
\hline Variable & Mean & Min & Max & N \\
\hline Age & $39.49(12.46)$ & 18 & 64 & 23,430 \\
Male & $0.4953(0.5000)$ & 0 & 1 & 23,430 \\
Married & $0.6848(0.4646)$ & 0 & 1 & 23,430 \\
Living in East Germany & $0.3785(0.4850)$ & 0 & 1 & 23,430 \\
\# Children in HH & $0.7441(0.9638)$ & 0 & 6 & 23,430 \\
\# Person in HH & $3.1233(1.1899)$ & 1 & 8 & 23,430 \\
No high school degree & $0.1824(0.3862)$ & 0 & 1 & 23,430 \\
High school degree & $0.6830(0.4653)$ & 0 & 1 & 23,430 \\
More than high school degree & $0.1347(0.3414)$ & 0 & 1 & 23,430 \\
Full-time employed & $0.5786(0.4938)$ & 0 & 1 & 23,430 \\
Unemployed & 0.2483 & 0 & 1 & 23,430 \\
Monthly net income (DM) & $1863.19(1306.56)$ & 32 & 20,000 & 23,430 \\
State unemployment rates $(\%)$ & & & & 7.0 \\
\multicolumn{1}{l}{1990} & 4.01 & 3.7 & 13.5 & 7810 \\
1991 & 7.77 & 4.4 & 16.8 & 7810 \\
1992 & 9.68 & & & 7.5 \\
\hline
\end{tabular}

Standard deviations are shown in parentheses

significantly immediately after 1990 . Within 2 years, average state unemployment rates in Germany were more than twice as high as prior to reunification.

Table 2 provides descriptive time use statistics. The first three columns show daily time use information from the GSOEP, while the final column shows statistics from the 1991/1992 German Time Use Survey (GTUS). The GSOEP statistics show that, on average, work time by all Germans declined by slightly more than half an hour in the 2 years after reunification. While time allocated toward nonmarket work appears to remain unchanged, the GSOEP data shows increases in time spent on leisure, education and childcare after 1990. The GTUS statistics, conducted by the Federal Statistical Office and carried out in the context of representative quota samples of all private household in Germany, provide some validity to the GSOEP time use data (for an overview of the GTUS, see Ehling, 1999). The differences in average time spent on the five categories of time use, relatively small differences are found for market and nonmarket work, education, and childcare. Only leisure shows substantial differences between the two data sets, with total leisure time being $2 \mathrm{~h}$ greater in the GTUS data. ${ }^{4}$ Overall, the GSOEP data accounts for up to $13.54 \mathrm{~h}$ of the day, while the GTUS time for the five listed categories accounts for $16.08 \mathrm{~h}$. The remaining time in the GTUS data is reported time spent sleeping, which is not included in the GSOEP survey.

\footnotetext{
${ }^{4}$ One potential explanation for the difference in leisure time is that the GTUS question about leisure is more detailed. It asks respondents to report time spent on free-time activities and 'media use' (German Time Use Survey). In the GSOEP, respondents are asked to indicate how much time they spend on hobbies and other free-time activities on a typical day. In addition, people might underestimate the time allocated toward leisure activities survey recall questions compared to when providing the information in detailed diary entries.
} 
Table 2 Time use summary statistics

\begin{tabular}{|c|c|c|c|c|}
\hline & GSOEP data & & & GTUS data \\
\hline & 1990 & 1991 & 1992 & 1991/1992 \\
\hline Market work & $6.75(4.28)$ & $6.22(4.43)$ & $6.17(4.50)$ & 6.67 \\
\hline Nonmarket work & $3.70(3.08)$ & $3.74(2.61)$ & $3.81(2.66)$ & 3.97 \\
\hline Leisure & $1.22(1.54)$ & $1.60(1.57)$ & $1.61(1.73)$ & 3.67 \\
\hline Education & $0.34(1.35)$ & $0.55(0.72)$ & $0.59(1.79)$ & 0.55 \\
\hline Childcare & $0.87(2.19)$ & $1.31(2.19)$ & $1.36(2.93)$ & 1.22 \\
\hline Total time & 12.88 & 13.42 & 13.54 & 16.08 \\
\hline $\mathrm{N}$ & 7810 & 7810 & 7810 & 25,775 \\
\hline
\end{tabular}

Standard deviations for the GSOEP sample are shown in parentheses

\section{Econometric Methods}

\section{Main DD Model}

This study employs a difference-in-differences (DD) model to test for the average treatment effects of the institutional and economic changes in Germany in 1990 on time allocation of East Germans. The main treatment group consists of individuals living in East Germany during the study period (1990 to 1992), whereas individuals living in West Germany form the control group of the study. This selection into groups provides the analysis with 6920 and 9867 observations for the treatment and control group, respectively.

The main DD equation estimated in this study is the following:

$$
\mathrm{Y}_{\mathrm{it}}=\beta_{0}++\delta_{\mathrm{DD}} \text { Post }_{\mathrm{it}}{ }^{*} \text { Treat }_{\mathrm{it}}+\beta_{1} \mathrm{X}_{\mathrm{it}}+\lambda_{1} \text { State }_{\mathrm{it}}+\lambda_{2} \text { Year }_{\mathrm{it}}+\varepsilon_{\mathrm{it}} \text {, }
$$

where $Y_{\text {it }}$ represents minutes allocated towards different categories of time use per weekday. Treat ${ }_{i t}$ equals one if an individual belongs to the treatment group, while Post is an indicator for the post-treatment period. In the main specification, I use 1992 as the post-treatment period, allowing 1991 to be the period of treatment. In two alternative models, I use only 1991 as well both 1991 and 1992 as post-treatment periods. ${ }^{5} \delta_{\mathrm{DD}}$, which represents the effect of reunification on time allocation, is the main parameter of interest. $\mathrm{X}_{\mathrm{it}}$ denotes a set of individual and household characteristics that are controlled for in the analysis. These include marital status, education, household size, the number of children in the household. Equation (1) also includes state and year dummy variables. I estimate ordinary least squares (OLS) models to examine the effects of reunification on time allocation using Eq. (1).

The main DD specification of the paper uses repeated cross-sectional data from the GSOEP. In additional specifications, I also estimate treatment effects while adding individual fixed effects to Eq. (1) by using the longitudinal nature of the data. The only difference between the two approaches in the context of this study is that unobserved

\footnotetext{
5 The results remain identical for these two additional specifications, which suggests that the effects of reunification on time use were already observable shortly after the events of 1990 .
} 
heterogeneity and potential measurement errors in self-report time use cancel out on average using repeated cross-sections, while canceling out a the individual level with the panel data. There seems to be no obvious reason why one of the approaches is superior over the other given the research question at hand.

Table 3 presents separate summary statistics for the treatment and the control group from the first sample period used in the study, which was conducted before reunification. While the two groups are identical regarding age and gender, it appears that East Germans are, on average, more likely to be married and have more children than respondents in West Germany. A potential explanation for these differences in marital status and the number of children between the two samples were specific policies that were in place in East Germany before reunification, which were pronatalistic and contained regulations that supported early marriages (Konietzka and Kreyenfeld 2001). These policies included "home furnishing loans" of 7000 Marks and priority access to apartments as well as money transfers and in-kind subsidies to reduce the cost of childcare for married households.

Additionally, differences in time use are observable before reunification. East Germans report to work longer, spend more time on nonmarket work, education, and childcare, with the differences being largest for work and nonmarket work. Given that the GSOEP only started West Germans regarding their leisure time in 1991 (East Germans were asked about leisure time starting 1990), the leisure statistics in Table 3 are from 1991. They show that, shortly after reunification, West Germans spend $102 \mathrm{~min}$ on leisure per day, which is substantially more than East Germans spend on leisure prior to reunification $(73 \mathrm{~min}$ ).

A main assumption of any DD model is that the two groups share a common trend and that they would have experienced similar trends in the absence of the policy change. While the GSOEP data does not allow me to go back in time further in time prior to reunification, I believe there is suggestive evidence that time use remained consistent in the years prior to 1990 in both German regions. In August 1967, the East German leadership introduced the 5-day working week of $43.75 \mathrm{~h}$, which remained in

Table 3 Descriptive statistics by region (Pre-Reunification)

\begin{tabular}{lll}
\hline Variable & East Germany & West Germany \\
\hline Age & $38.28(11.99)$ & $38.42(12.82)$ \\
Male & $0.4932(0.5000)$ & $0.4965(0.5000)$ \\
Married & $0.7415(0.4379)$ & $0.6372(0.4809)$ \\
\# Children in HH & $0.9276(0.9714)$ & $0.6599(0.9452)$ \\
At most high school degree & $0.8968(0.3042)$ & $0.8269(0.3783)$ \\
Work time per day & $486.78(208.99)$ & $361.20(311.85)$ \\
Nonmarket work time per day & $267.97(176.08)$ & $193.58(184.00)$ \\
Education time per day & $23.38(85.85)$ & $18.90(95.71)$ \\
Childcare time per day & $72.75(142.77)$ & $39.51(122.25)$ \\
Leisure time per day (1991) & $85.53(92.06)$ & $102.06(95.16)$ \\
$\mathrm{N}$ & 2956 & 4854 \\
\hline
\end{tabular}

Standard deviations are shown in parentheses 
place until reunification. Similarly, in West Germany, working weeks were set at $38.5 \mathrm{~h}$ in 1984, a regulation that remained in place until 1995 (Strawe 1994). Kratzer et al. (2005) provide evidence that work times in West Germany changed very little between 1984 and 1990. The authors show that the biggest change in weekly hours worked is found for individuals with low education, who reduced their work time by $1.9 \mathrm{~h}$ per week. Krueger and Pischke (1995) point out that, despite different political systems in the two regions, rate of returns to education were identical in East and West Germany in 1988. The authors mention that the absence of educational fees as well as the presence of a widely used apprenticeship system that was tied to public schools are further similarities between the two regions. The next section introduces two alternative DD models that can further test for the validity of assumptions made in the baseline DD model.

\section{Alternative DD Models}

Additionally, I estimate a semi-parametric DD model, which was introduced by Abadie (2005). The method captures average treatment effects for the treated group (ATT) for the case that differences in observed characteristics create non-parallel outcome dynamics between the two observed groups, which violates the main assumption of standard DD models. The ATT is given by the following equation:

$$
E\left[Y^{1}(1)-Y^{0}(1) \mid D=1\right]=E\left[\frac{P(D=1 \mid X)}{P(D=1)} * \varphi_{o} * Y\right],
$$

where $\mathrm{Y}(1)$ and $\mathrm{Y}(0)$ represent time use outcomes before and after the treatment, $\mathrm{D}$ is an indicator for belonging to the treatment group, $\mathrm{P}(\mathrm{D}=1)$ gives the probability of receiving treatment, and $\mathrm{P}(\mathrm{D}=1 \mid \mathrm{X})$ is the propensity score that equals the probability of treatment, conditional on the observed covariates $\mathrm{X}$. The propensity scores for the semi-parametric analysis are obtained using probit estimation. ${ }^{6}$ The value of $\varphi_{0}$ is obtained from the following equation:

$$
\varphi_{0}=\frac{T-\gamma}{\gamma^{*}(1-\gamma)} * \frac{D-P(D=1 \mid X)}{P(D=1 \mid X) * P(D=0 \mid X)},
$$

where $\mathrm{T}$ is a time indicator that equals one if the observation belongs to the posttreatment period and $\gamma$ reflects the proportion of observations sampled in the posttreatment period. Abadie (2005) shows that the semi-parametric estimator is obtained through two steps: 1) Estimation of the propensity score and computation of fitted values for the sample; and 2) Plugging in the obtained fitted values into the sample analogue of Eq. (4) to obtain average treatment effects for the treated. According to Abadie (2005), simple weighted average differences in the outcome of interest over time can recover estimates for treatment effects, while the weights depend on the

\footnotetext{
${ }^{6}$ I additionally re-estimate the propensity scores using the two other commonly used estimation techniques for propensity scores, logit and cloglog estimation. The results remain unchanged.
} 
propensity scores. This guarantees that the same distribution of covariates is imposed for the treatment and for the control group. The average estimated fitted values for the sample is $0.3262 .^{7}$ The standard errors for the semiparametric estimates are obtained through bootstrapping using 1999 replications.

Difference-in-Differences models require an assumption that trends in the variable of interest are similar for both treatment and control group in the absence of the policy change. This assumption implies that differences between the groups are assumed to be time-invariant without treatment. Mora and Reggio (2015) point out the fact that the identification of treatment effects does not only depend on the parallel trends assumption, but also on the trend modeling strategy applied by researchers. For example, Mora and Reggio show that DD estimates will differ substantially depending on whether group-specific linear trends or group specific invariant linear trends are included in the analysis in order to accommodate for trend differentials between treatment and control group. By arguing that researchers often overlook this fact, the authors introduce an alternative DD estimator, which identifies the effect of the policy using a fully flexible dynamic specification and includes a family of alternative "parallel growth" assumptions (Mora and Reggio 2015). The two main advantages the authors list in favor of their DD estimate are that it: 1) allows for flexible dynamics and for testing restrictions on these dynamics; 2) does not impose equivalence between alternative parallel assumptions. Following Mora and Reggio (2015), who provide Stata code to implement their alternative DD specification, this alternative estimator is acquired in two steps: In the first step, standard least squares estimation of the fully flexible model is conducted. In the second step, the solution of the equation in differences identifies the treatment effects. More and Reggio's DD fully flexible DD estimator is obtained from the following equation:

$$
E\left[Y_{t} \mid D\right]=\delta+\sum_{\tau=t_{2}}^{T} \delta_{\tau} I_{\tau, t}+\gamma^{D} D+\sum_{\tau=t_{2}}^{T} \gamma_{\tau}^{D} \times I_{\tau, t} \times D
$$

where $\mathrm{I}_{\tau, \mathrm{t}}$ is a dummy for period $\tau, \gamma^{\mathrm{D}}$ is a control for group differences in linear trends. Estimating Mora and Reggio's alternative model allows testing for the validity of standard DD assumptions made in the baseline specification of this study.

\section{Results}

\section{Main DD Model}

Table 4 shows the main DD estimates for the effects of the institutional and economic changes on time allocation of individuals living in East Germany. Panel A presents estimates for the effects on time spent on four different activities for the entire sample. The result in column (1) indicates that East Germans allocated 96.43 min less on market work per weekday $(p<0.01)$, which corresponds to a decline in work time of

\footnotetext{
${ }^{7}$ Histograms of the propensity scores for the pre- and post-policy period provide evidence that there is a common support for the groups in both periods. The histograms are not shown in the paper, but are available upon request.
} 
Table 4 The effects of reunification on time use (Repeated Cross-Sections)

\begin{tabular}{lllll}
\hline Panel A: All & Market Work & Nonmarket Work & Education & Childcare \\
& $(1)$ & $(2)$ & $(3)$ & $(4)$ \\
Post*Treat & $-96.43 * * *(8.16)$ & $-51.14 * * *(5.17)$ & $-5.59 *(3.04)$ & $-42.09 * * *(4.28)$ \\
Percent change & $-19.81 \%$ & $-19.08 \%$ & $-23.91 \%$ & $-57.86 \%$ \\
N & 16,787 & 16,787 & 16,787 & 16,787 \\
Panel B: Other & Leisure Time & & Spent Time on Job Search \\
\multicolumn{1}{c}{ Activities (All) } & & & & West \\
& East & West & East & - \\
1990 & $74.63 \min (93.85)$ & - & - & $0.1014(0.3018)$ \\
1991 & $88.49 \min (95.74)$ & $103.05(96.43)$ & $0.1778(0.3824)$ & $0.1067(0.3088)$ \\
1992 & $91.53 \min (106.61)$ & $100.67(102.30)$ & $0.1967(0.3976)$ & 0.1067 \\
\hline
\end{tabular}

Robust standard errors, clustered at the state-level, are shown in parentheses in Panel A and B. Panel A and B include controls for the number of children, number of household members, marital status, education as well as a set of year and state dummies. ${ }^{*} p<0.10,{ }^{* *} p<0.05,{ }^{* * *} p<0.01$. In Panel $\mathrm{B}$, standard deviations are shown in parentheses

$19.81 \%$ change compared to before reunification. Columns (2) and (4) shows that East Germans additionally reduced the time allocated toward nonmarket work and childcare by 51.14 and 42.09 min per day, respectively (both $p<0.01$ ). The finding on nonmarket work is different from results for the Great Recession in the U.S. by Aguiar et al. (2013), who show that $30 \%$ of forgone work time is reallocated toward nonmarket activities. The observed reduction in childcare time for East Germans is consistent with recent evidence showing that East Germany experienced strongly declining birth rates following reunification (Chevalier and Marie 2017; Witte and Wagner 1995). Finally, I find that East Germans reduce the time they spent on educational activities by $5.59 \mathrm{~min}$ per weekday $(p<0.10)$, which corresponds to a $23.91 \%$ reduction.

Panel B provides descriptive statistics for changes in two other activities during the time of the analysis: 1) leisure ${ }^{8}$ and 2) job search. The statistics for leisure time show that East Germans increased the amount of time allocated toward free-time activities by 16.90 min per weekday between 1990 and 1992. For individuals living in West Germany, who spend more time on leisure overall, no changes are noticeable between 1991 and 1992. Additionally, Panel B shows that 18.10 and 20.09\% of East Germans spend some time searching for new employment in 1991 and 1992, respectively. This share is substantially larger than in West Germany (10.14 and 10.67\%). ${ }^{9}$ Despite solely providing changes in descriptive statistics, Panel B suggests that East Germans reallocated time from work (market and nonmarket) and childcare activities toward additional leisure time and time spent on searching for employment. However, given that the increases in leisure correspond to only small proportions of the reductions in

\footnotetext{
${ }^{8}$ Given that, in the only sample before reunification, the GSOEP only includes information on leisure time for individuals in East Germany, I am unable to estimate the effects of reunification on time allocated toward leisure activities using the DD model.

${ }^{9}$ Information on whether respondents searched for employment only became available in 1991 in the GSOEP. The survey asks individuals whether they searched for a job in the previous year through employment offices, newspapers, friends, or other means.
} 
work and childcare, the statistics also suggest that East Germans spent more time on activities that they did not report in the survey after reunification.

Table 5 additionally shows the results obtained from estimating the effects of reunification on time use when including individual fixed effects in the specifications. The estimates in Panel A are equivalent to those in Panel A of Table 4, with the only difference being that unobserved heterogeneity is cancelled out at the individual level rather than on average. It is noticeable that the results remain almost identical to the repeated cross-section analysis. In Panel B, I furthermore use the longitudinal nature of the GSOEP to test whether changes in time use were also observable for individuals who remained employed in all 3 years of the sample (1990 to 1992). These findings could provide some first suggestive evidence indicating whether the previously shown large changes in times use by East Germans were the result of external or internal factors of reunification. Panel B shows that the reductions in time allocated towards work $(10.73 \mathrm{~min}$, $p<0.10)$ and childcare $(7.65 \mathrm{~min}, p<0.05)$ are substantially smaller for individuals who remained employed compared to the entire sample, whereas the reduction in nonmarket time $(76.59 \mathrm{~min}, p<0.01)$ is larger. East German workers also allocate 9.94 additional minutes $(p<0.01)$ towards education compared to employed West Germans following reunification. The results in Panel B suggest that the large reductions in work and childcare time for the entire sample are for the most part driven by people losing their employment after reunification, but part of the changes in time use is also coming from working individuals, which might be driven by factors besides labor market outcomes.

A limitation of conditioning the sample on employment, an endogenous decision by individuals, is that it likely introduces Heckman-type sample selection, which could further complicate the identification. Thus, the results

Table 5 The effects of reunification on time use (Panel)

\begin{tabular}{lllll}
\hline Panel A: All & Market Work & Nonmarket Work & Education & \multicolumn{2}{c}{ Childcare } \\
& $(1)$ & $(2)$ & $(3)$ & $(4)$ \\
Post*Treat & $-99.58 * * *(6.31)$ & $-54.11 * * *(4.25)$ & $-4.55(2.91)$ & $-42.96 * * *(3.61)$ \\
Percent Change & $-20.46 \%$ & $-20.19 \%$ & $-19.46 \%$ & $-59.05 \%$ \\
N & 15,620 & 15,620 & 15,620 & 15,620 \\
Panel B: Workers Only & & & \\
$\quad$ Post*Treat & $-10.73 *(6.05)$ & $-76.59 * * *(4.79)$ & $9.94 * * *(2.52)$ & $-7.65 * *(3.35)$ \\
$\quad$ Percent Change & $-2.02 \%$ & $-29.58 \%$ & $68.98 \%$ & $-10.39 \%$ \\
$\quad$ N & 11,752 & 11,752 & 11,752 & 11,752 \\
Panel C: Workers Only & $($ Heckman Selection & Model $)$ & & $-8.08 * *(3.80)$ \\
Post*Treat & $-6.90(6.90)$ & $-79.08 * * *(5.14)$ & $1.09(2.77)$ & $-10.97 \%$ \\
Percent Change & $-1.30 \%$ & $-30.54 \%$ & $7.56 \%$ & 11,752 \\
$\quad$ N & 11,752 & 11,752 & 11,752 & \\
\hline
\end{tabular}

Robust standard errors, clustered at the state-level, are shown in parentheses. All models include controls for the number of children, number of household members, marital status, as well as a set of year and state dummies

$$
{ }^{*} p<0.10,{ }^{* *} p<0.05,{ }^{* * *} p<0.01
$$


in Panel B should be viewed with caution. Heckman's (1979) two-step sample selection model is able to correct for this potential sample selection bias by including the inverse Mill's ratio in the DD specification. The results from these additional specifications are shown in Panel $\mathrm{C}$, whereas standard errors are obtained by bootstrapping with 1999 replications in order to adjust for the first step. The estimates for work time confirm the potential presence of sample selection bias in Panel B by showing a statistically insignificant reduction of only $6.90 \mathrm{~min}$ for East Germans who are working during the sample period. While the results for time spent on nonmarket work and childcare remain fairly similar, the Heckman model finds no effects on education time.

\section{Alternative DD Models}

Table 6 presents results from the semiparametric DD model (Abadie 2005) and the alternative DD model introduced by Mora and Reggio (2015). Panel A shows that the negative effects of reunification on market work time obtained from the semiparametric DD model $(101.74 \mathrm{~min}, p<0.01)$ is almost identical to the result from the baseline DD model $(96.43, p<0.01)$. Similarly, the observed effects on nonmarket work are consistent with the main DD effects shown in Table 4. Furthermore, the semiparametric DD model finds no effects on time spent on education, while providing evidence for even larger reduction in time allocated towards childcare $(81.14 \mathrm{~min}, p<0.01)$ than the main results.

The results obtained by Mora and Reggio's (2015) alternative DD specification, shown in Panel B, also confirm that East Germans reduced the time they allocated towards market work, nonmarket work, and childcare. These three estimates are statistically significant $(p<0.01)$, but the sizes of the effects are smaller than the main DD effects. Despite the difference in magnitudes, the

Table 6 The effects of reunification on time use (Additional DD Models)

\begin{tabular}{lllll}
\hline & $\begin{array}{l}\text { Market work } \\
(1)\end{array}$ & $\begin{array}{l}\text { Nonmarket work } \\
(2)\end{array}$ & $\begin{array}{l}\text { Education } \\
(3)\end{array}$ & $\begin{array}{l}\text { Childcare } \\
(4)\end{array}$ \\
\hline Panel A: Semiparametric DD (Abadie) & & & \\
Post*Treat & $-101.74 * * *(19.23)$ & $-56.79 * * *(11.71)$ & $-0.23(3.71)$ & $-81.14 * * *(8.01)$ \\
Percent Change & $-20.90 \%$ & $-21.19 \%$ & $-0.98 \%$ & $-111.53 \%$ \\
N & 15,620 & 15,620 & 15,620 & 15,620 \\
Panel B: Alternative DD (Mora \& Reggio) & & & \\
Post*Treat & $-47.61 * * *(7.40)$ & $-24.11 * * *(4.40)$ & $2.40(2.80)$ & $-24.64 * * *(3.90)$ \\
Percent Change & $-9.78 \%$ & $-9.00 \%$ & $10.27 \%$ & $-33.87 \%$ \\
N & 15,620 & 15,620 & 15,620 & 15,620 \\
\hline
\end{tabular}

For the estimates in Panel A, the standard errors, shown in parentheses, are obtained through bootstrapping using 1999 replications. In Panel B, robust standard errors, clustered at the state-level, are shown in parentheses. All models include controls for the number of children, number of household members, marital status, as well as a set of year and state dummies

${ }^{*} p<0.10,{ }^{* *} p<0.05,{ }^{* * *} p<0.01$ 
results in Panel B provide additional validity for the baseline DD assumptions in the main specifications of the study.

\section{External Versus Internal Effects of Reunification}

Table 7 presents estimates from four additional specifications. For the analysis in Panel A, the sample is narrowed down to individuals who were employed prior to reunification (1990), but became unemployed in 1991 or 1992. East German "job losers" form the treatment group, while newly unemployed people in West Germany form the control group. Despite a relatively small sample size, the results from this specification can provide additional evidence for the role of external effects of reunification on time use, such as the institutional and economic changes that occurred in East Germany in 1990. Column (1) shows that work time of East German "job losers" is reduced by 42.37 additional minutes per weekday $(p<0.10)$ for East Germans, which corresponds to $3.53 \mathrm{~h}$ per week. This suggests that East Germans potentially had more difficulty finding a new job after becoming unemployed and that other factor besides labor market conditions affected the time use of East Germans following reunification.

Panel B shows DD effects comparing changes in time use among individuals who remained employed throughout all three survey years in East (treatment group) and West Germany (control group). I find a reduction in work time by 10.92 min per weekday $(p<0.10)$ and an even larger reduction in nonmarket work time of 76.72 min per weekday $(p<0.01)$ for "job keepers" in East Germany. Working individuals in the East also spend more time on education $(p<0.01)$ and less time on childcare $(p<0.01)$ following reunification. Again, these findings provide evidence that external factors affected the allocation of time in East Germany after the events of 1990.

Finally, I examine whether the effects of reunification on time use differ between states that experienced larger increases in state unemployment rates (compared to the average UR increase) and those whose increases in state unemployment rates were relatively small. While average unemployment rates increased in both regions after reunification, these increases were substantially larger in East Germany. Thus, I conduct this analysis separately for the two regions using state unemployment rates, collected by the Bundesagentur für Arbeit. Panel C shows the estimates for East Germany, where the treatment group consists of the three states that experienced larger increases in unemployment rates (MecklenburgVorpommern and Saxony-Anhalt, and Thuringia). ${ }^{10}$ The estimates in Panel $\mathrm{C}$ indicate relative small differences in time use across the two groups of states, suggesting that changes in labor market conditions were not the only driver of time allocation changes in East Germany. Similarly, the same analysis for West Germany find no statistically significant differences in time use changes across states with larger and smaller increases in unemployment rates (Panel D). ${ }^{11}$

\footnotetext{
${ }^{10}$ The average increases in unemployment rates between 1990 and 1992 was 14.83 percentage points for the treatment states and 12.60 for the control states.

${ }^{11}$ Treated states with above-average increases in unemployment rates are: Baden-Wuerttemberg, Bavaria, North-Rhine-Westfalia, and Rheinland-Pfalz.
} 


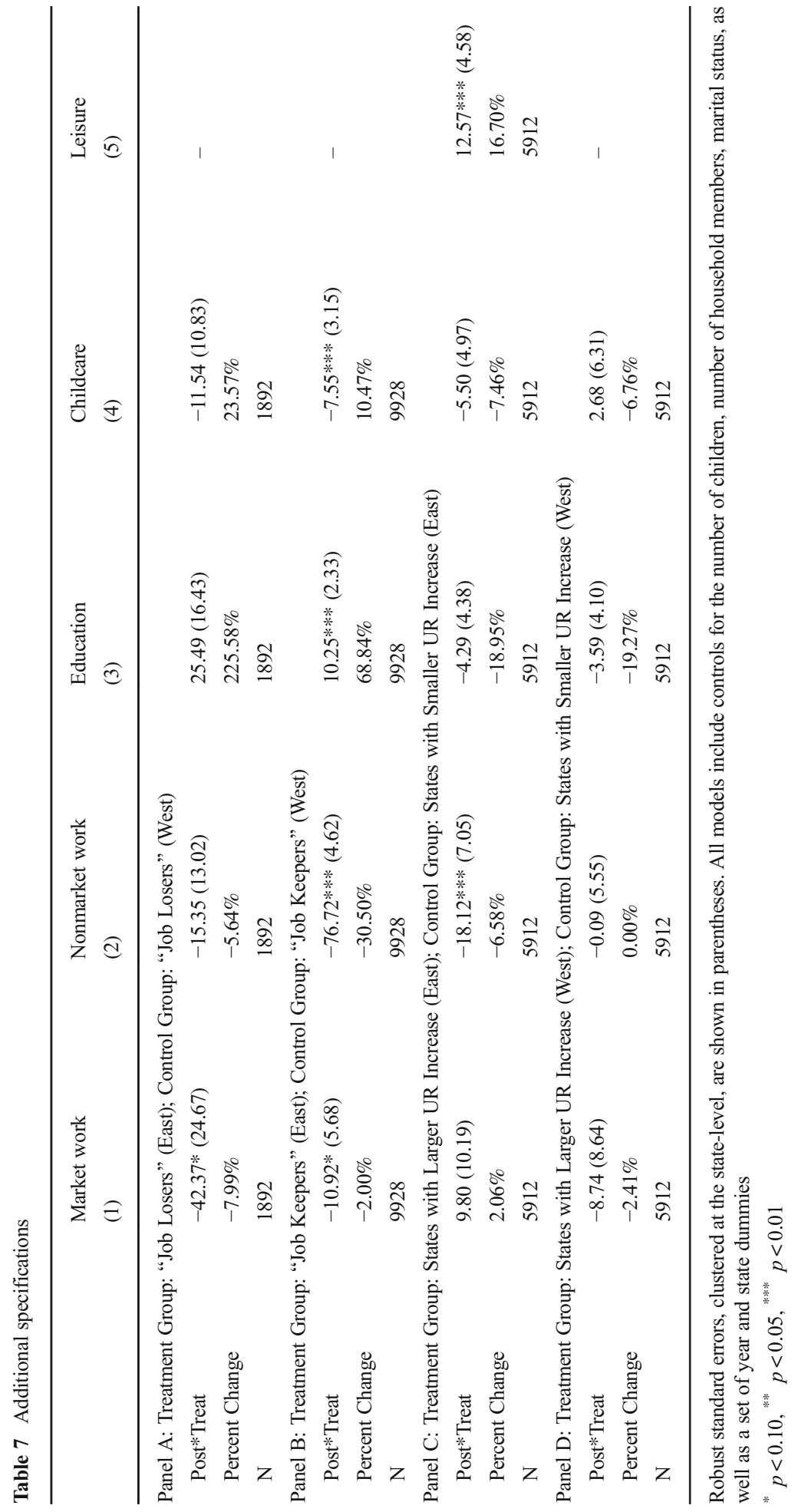


Table 8 The effects of reunification on time use across population subgroups

\begin{tabular}{|c|c|c|c|c|c|}
\hline & $\begin{array}{l}\text { Market work } \\
\text { (1) }\end{array}$ & $\begin{array}{l}\text { Nonmarket } \\
\text { work } \\
\text { (2) }\end{array}$ & $\begin{array}{l}\text { Education } \\
\text { (3) }\end{array}$ & $\begin{array}{l}\text { Childcare } \\
\text { (4) }\end{array}$ & $\mathrm{N}$ \\
\hline Male & $\begin{array}{c}-102.22 * * * \\
(9.16)\end{array}$ & $\begin{array}{c}-46.62 * * * \\
(5.56)\end{array}$ & $\begin{array}{c}-14.39 * * * \\
(4.31)\end{array}$ & $-0.28(2.59)$ & 7736 \\
\hline Female & $\begin{array}{c}-97.18 * * * \\
(8.68)\end{array}$ & $\begin{array}{c}-61.39 * * * \\
(6.44)\end{array}$ & $-4.85(3.88)$ & $\begin{array}{c}-84.04 * * * \\
(6.54)\end{array}$ & 7784 \\
\hline Less than high school & $\begin{array}{c}-155.65 * * * \\
(20.82)\end{array}$ & $\begin{array}{c}-57.87 * * * \\
(14.69)\end{array}$ & $\begin{array}{r}-20.98^{*} \\
(11.69)\end{array}$ & $\begin{array}{r}-23.78 * * \\
(11.65)\end{array}$ & 2789 \\
\hline High school & $\begin{array}{c}-97.62^{* * * *} \\
(7.82)\end{array}$ & $\begin{array}{c}-50.77 * * * \\
(5.18)\end{array}$ & $2.26(3.08)$ & $\begin{array}{c}-44.36 * * * \\
(4.57)\end{array}$ & 10,554 \\
\hline More than high school & $\begin{array}{c}-51.01 * * * \\
(17.61)\end{array}$ & $\begin{array}{c}-69.11 * * * \\
(11.76)\end{array}$ & $-4.35(5.39)$ & $\begin{array}{c}-52.42 * * * \\
(10.98)\end{array}$ & 2078 \\
\hline$<40$ th income percentile & $\begin{array}{c}-184.88 * * * \\
(13.57)\end{array}$ & $\begin{array}{c}-51.09 * * * \\
(10.66)\end{array}$ & $\begin{array}{c}-28.37 * * * \\
(8.67)\end{array}$ & $\begin{array}{c}-86.62 * * * \\
(10.10)\end{array}$ & 6670 \\
\hline 40th-80th income percentile & $\begin{array}{r}-38.69^{* *} \\
(19.79)\end{array}$ & $\begin{array}{c}-65.51 * * * \\
(20.89)\end{array}$ & $9.97(8.39)$ & $18.31(17.70)$ & 2990 \\
\hline$>80$ th income percentile & $8.75(11.30)$ & $\begin{array}{c}-84.34 * * * \\
(10.18)\end{array}$ & $1.32(4.29)$ & $-11.58(7.09)$ & 5960 \\
\hline Age $18-29$ & $\begin{array}{c}-77.36 * * * \\
(15.50)\end{array}$ & $\begin{array}{c}-57.19 * * * \\
(8.15)\end{array}$ & $\begin{array}{c}-61.87 * * * \\
(10.36)\end{array}$ & $\begin{array}{c}-62.94 * * * \\
(10.91)\end{array}$ & 4142 \\
\hline Age $30-45$ & $\begin{array}{c}-76.35 * * * \\
(10.20)\end{array}$ & $\begin{array}{c}-69.25 * * * \\
(7.50)\end{array}$ & $\begin{array}{c}13.52 * * * \\
(3.68)\end{array}$ & $\begin{array}{c}-62.21 * * * \\
(6.91)\end{array}$ & 6103 \\
\hline Age $46-64$ & $\begin{array}{c}-146.50 * * * \\
(11.58)\end{array}$ & $\begin{array}{c}-29.29 * * * \\
(8.39)\end{array}$ & $8.11 * * *(2.59)$ & $-2.74(2.90)$ & 5375 \\
\hline Agriculture/Energy/Mining & $-26.62(54.03)$ & $\begin{array}{c}-36.35 * * * \\
(15.61)\end{array}$ & $12.09(11.70)$ & $-3.47(10.74)$ & 835 \\
\hline Manufacturing/Construction & $\begin{array}{c}-80.18 * * * \\
(10.00)\end{array}$ & $\begin{array}{c}-36.45 * * * \\
(6.73)\end{array}$ & $\begin{array}{c}16.18 * * * \\
(3.75)\end{array}$ & $3.89(3.92)$ & 4276 \\
\hline Trade/Transport & $-19.14(11.69)$ & $\begin{array}{c}-57.64 * * * \\
(11.17)\end{array}$ & $7.12(4.46)$ & $5.12(6.46)$ & 2201 \\
\hline Services & $-22.25^{* *}(8.89)$ & $\begin{array}{c}-61.38 * * * \\
(7.73)\end{array}$ & $\begin{array}{c}12.44 * * * \\
(4.10)\end{array}$ & $1.11(5.45)$ & 3495 \\
\hline
\end{tabular}

Robust standard errors, clustered at the state-level, are shown in parentheses in Panel A and B. All models in Panel A and B include controls for the number of children, number of household members, marital status, as well as a set of year and state dummies. ${ }^{*} p<0.10,{ }^{* *} p<0.05,{ }^{* * *} p<0.01$

\section{Heterogeneous Effects on Time Use}

Next, I examine whether the institutional and economic changes that occurred in East Germany differently affected time use of various subgroups of the population. The effects across gender as well as different education, age, income, and occupation groups are presented in Table 8 . The gender results indicate that both males and females reduced their work time similarly. However, differences in other time categories are noticeable. East German men experience a larger reduction in education time, while women reduce more time allocated toward nonmarket work activities. The biggest difference is found for time spent on childcare: while men do not alter their childcare 
Table 9 Changes in Leisure and Job Search Activities for East Germans

\begin{tabular}{llll}
\hline & $\begin{array}{l}\text { Change in leisure time in } \\
\text { East Germany }(1990 \text { to } 1992)\end{array}$ & Share of job searchers in East Germany \\
& & 1991 & 1992 \\
\hline Male & $16.58 \mathrm{~min}$ & $0.2051(0.4039)$ & $0.2222(0.4159)$ \\
Female & $17.98 \mathrm{~min}$ & $0.1575(0.3644)$ & $0.1802(0.3845)$ \\
Less than high school & $13.70 \mathrm{~min}$ & $0.1085(0.3116)$ & $0.0830(0.2764)$ \\
High school & $18.14 \mathrm{~min}$ & $0.1883(0.3911)$ & $0.2131(0.4096)$ \\
More than high school & $24.11 \mathrm{~min}$ & $0.1890(0.3922)$ & $0.2021(0.4027)$ \\
$<40$ th income \% & $36.45 \mathrm{~min}$ & $0.1008(0.3011)$ & $0.0774(0.2674)$ \\
40th-80th income \% & $9.77 \mathrm{~min}$ & $0.1861(0.3893)$ & $0.2824(0.4504)$ \\
$>80$ th income \% & $-4.04 \mathrm{~min}$ & $0.3333(0.4718)$ & $0.2909(0.4545)$ \\
Age 18-29 & $12.73 \mathrm{~min}$ & $0.1912(0.3935)$ & $0.2063(0.4050)$ \\
Age 30-45 & $10.61 \mathrm{~min}$ & $0.2158(0.4115)$ & $0.2388(0.4265)$ \\
Age 46-64 & $30.94 \mathrm{~min}$ & $0.1292(0.3357)$ & $0.1501(0.3574)$ \\
Agriculture/Energy/Mining & $13.50 \mathrm{~min}$ & $0.1131(0.3173)$ & $0.1576(0.3654)$ \\
Manufacturing/Construction & $-0.90 \mathrm{~min}$ & $0.2125(0.4093)$ & $0.2784(0.4486)$ \\
Trade/Transport & $7.98 \mathrm{~min}$ & $0.2736(0.4463)$ & $0.2484(0.4325)$ \\
Services & $10.60 \mathrm{~min}$ & $0.2485(0.4325)$ & $0.3238(0.4683)$ \\
\hline
\end{tabular}

Standard deviations are shown in parentheses

participation, East German women reduce their childcare time by 84.04 min per weekday compared to women in West Germany following reunification.

Individuals without a completed high school degree have the largest reduction of market work time (155.65 min per weekday), while those who obtained additional schooling after completing high school experience the smallest decline $(51.01 \mathrm{~min})$. This suggest that reunification had the largest effects on the labor market outcomes of low educated East Germans. Consistent with this, I find the largest reductions in market work time for low-income individual (below 40th income percentile). On average, this group works 184.88 min less per weekday compared to low-income respondents from West Germany. Individuals in the low-income group also reduce their childcare time the most, while also spending 28.37 less minutes on educational activities each weekday.

Table 8 also shows that the effects on market work time are largest for respondents above 45 years of age $(146.50 \mathrm{~min})$, a group for which the analysis also finds the smallest reductions in nonmarket work and childcare, as well as an increase in time allocated toward education. When examining differences in time use across occupation groups, the results indicate that individuals working in manufacturing and construction experienced the greatest drop in market work time, while workers in trade, transportation, and service have the largest decline in nonmarket work time.

In addition to the analysis of heterogeneous effects of reunification on time use, Table 9 provides descriptive changes in leisure time and in job search activities for the same subgroups in East Germany. For leisure time, the statistics show the change in the average time each subgroup spends on leisure activities between 1990 and 1992. It is 
noticeable that East Germans in the lowest income group experienced the largest increase in leisure time (36.45 min per weekday), followed by individuals between the ages 46 and 64 (30.94 min). Given that Table 8 indicated that these two groups experienced substantial reduction in market work time, Table 9 provides suggestive evidence that East Germans reallocated foregone market work time toward additional time spent on leisure activities. Interestingly, individuals in the two highest income groups have higher shares of individuals reporting that they have looked for new employment after reunification compared to the low-income group. The statistics on job search also show that East Germans above age 45 are, despite experiencing larger reductions in market work time, less likely to search for new employment than younger people. A possible explanation for this is that older individuals, who have lived their entire lives in a socialist system, are discouraged about finding new employment in the new economic system.

\section{Trends in Time Use Between East and West Germany (1990-2000)}

The previous section provided evidence that German Reunification significantly altered the time use of people living in East Germany. Next, I examine whether there was any convergence in time use of East Germans to time use of people in West Germany following the switch from socialism to capitalism and the several other changes that occurred in 1990. In order to compare trends between the two regions, I use data for the years 1990 to 2000, which provides information from one sample prior to reunification and for 10 years after reunification. Given that the initial economic shock in East Germany following reunification slowed down in the mid-1990s (Hunt 2008), this analysis can provide further evidence whether the previously observed changes in East

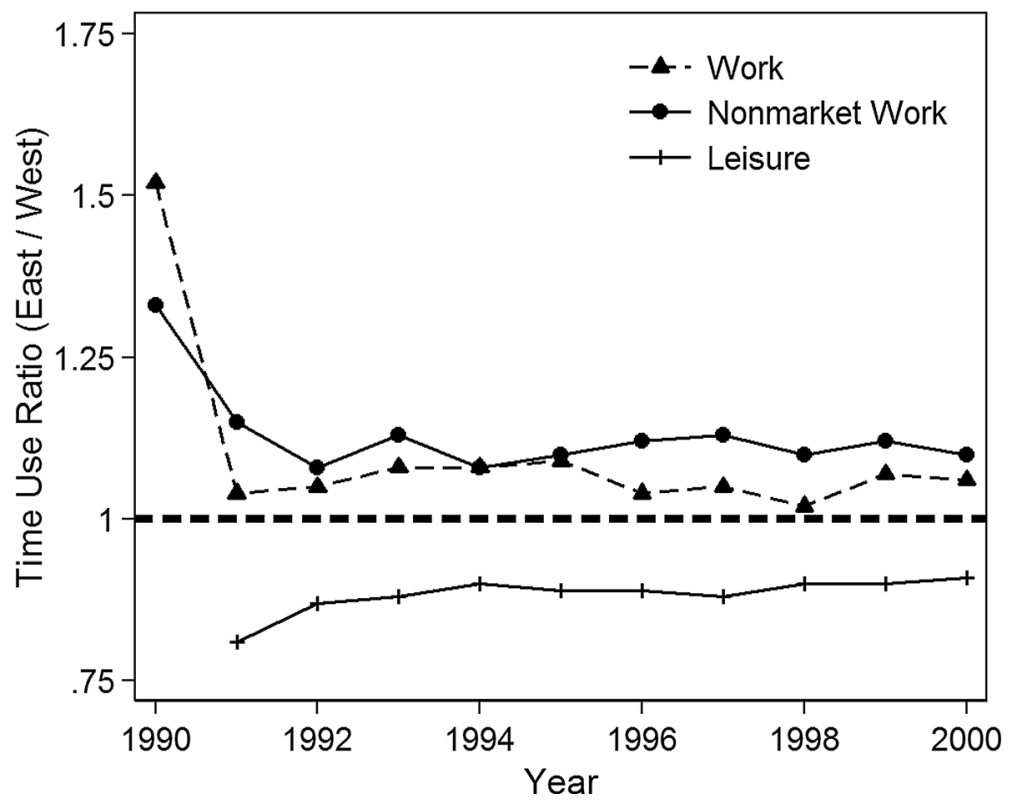

Fig. 1 Time use ratios (East Germany / West Germany) 
German time use are mainly driven by the large economic downturn or by the transition away from the communist ideology.

Figure 1 presents time use ratios (average time spent by East Germans divided by average time spent by West Germans) for market work, nonmarket work and leisure. The picture shows that East German time use became much closer to its West German counterpart following reunification and throughout the 1990s. East Germans still spend more time on market and nonmarket work, while enjoying less leisure time, the gap significantly narrowed following reunification. This convergence is mainly driven by the previously observed changes in time allocation in East Germany since time use remained similar in West Germany throughout the 1990s.

\section{Conclusions}

This study provides new evidence on how people alter their time use following the onset of large economic and institutional changes, a research questions that has previously not received much attention. The analysis examines effects of the German Reunification, an event that brought upon dramatic changes to the lives of East Germans and offers a setting close to a "natural" experiment. By using data from the GSOEP, the study finds significant reductions in market work time for individuals living in East Germany following reunification. Additionally, I find that East Germans reduce the time they allocate on nonmarket work activities and on childcare, while allocating more time on leisure activities.

When comparing trends in time use between East and West Germany, the study provides evidence for a convergence in time spent on several activities during the 1990s, which is mainly driven by changes in time use in East Germany. Hunt (2008) states that reunification can be considered a success in terms of improving the standard of living were it not for the problems with the labor market. My findings confirms this. East Germans started spending similar amount of time on leisure activities after 1990. Given that East Germans were working more and had less leisure time, this alone could be considered an improvement in social welfare if individuals value having a certain amount of leisure time. Schulze Buschoff (1997) provide evidence for this by showing that preferences for time spent at work among working people in East Germany declined after 1990 and became closer to preferences the preferences of West Germans. Similarly, Hunt (2008) points out that there was an immediate desire to purchase West German goods following reunification among East Germans who became exposed to a new cultural environment following the changes of 1990. While this suggests that reunification affected cultural and social values, it should be noted that, despite the fact that East Germans were working longer hours before reunification, productivity levels were far lower than in West Germany. Rather than leading to changes in time preferences, the dramatic changes in 1990 could have changed expected levels of work efforts in East Germany. Given that legal working weeks remained higher in East Germany throughout the 1990s and changes in working time policies were only implemented many years after reunification, the role of these policies in explaining the findings of this paper are likely relatively small.

When evaluating the overall welfare implications of reunification, however, the negative effects on labor market outcomes should also be considered. While GDP 
per capital and disposable income per worker increased substantially in East Germany reaching 66 and $83 \%$ their West German counterpart by 1995, respectively, unemployment rates is East Germany remained very high throughout the early 1990s. The improvements in quality of life for some individuals in East Germany after the region left the highly inefficient Socialist regime came at a cost for others. Thus, while the observed changes in time trends across the two regions in itself should not be considered problematic, policymakers should think about ways to avoid large economic shocks for transition economies following large structural changes to the system.

The findings suggest that large economic and institutional transitions strongly impact the everyday lives of people. The observed decline in nonmarket work time by East Germans following reunification is different from findings by Aguiar et al. (2013) for the Great Recession in the U.S., which show that around 30\% of foregone market work time is reallocated toward more time spent on nonmarket work. Potential explanations for the observed decline in nonmarket work and childcare in this study could be increases in economic uncertainty and overall stress for East Germans after being confronted with sudden economic and social changes. A task for future research should be to further examine mechanisms through which economic and institutional changes influence people's time allocation. This could help guide policymakers on how to reduce any potential losses in productivity and well-being during transition phases.

Acknowledgements I would like to thank Barry Hirsch as well as an anonymous referee for helpful comments and feedback on earlier versions of the paper.

Funding The author declares that he has received no funding to conduct the research.

\section{Compliance with Ethical Standards}

Conflict of Interest The author declares that he has no conflicts of interest.

Open Access This article is distributed under the terms of the Creative Commons Attribution 4.0 International License (http://creativecommons.org/licenses/by/4.0/), which permits unrestricted use, distribution, and reproduction in any medium, provided you give appropriate credit to the original author(s) and the source, provide a link to the Creative Commons license, and indicate if changes were made.

\section{References}

Abadie A (2005) Semiparametric Difference-in-Differences Estimators. Rev Econ Stud 72:1-19

Aguiar M, Hurst E (2007) Measuring Trends in Leisure: The Allocation of Time over Five Decades. Q J Econ 2007:969-1006

Aguiar M, Hurst E, Karabarbounis L (2013) Time Use During the Great Recession. Am Econ Rev 103(5): 1664-1696

Becker GS (1965) A Theory of the Allocation of Time. Econ J 75(299):493-517

Burda MC, Hunt J (2001) From Reunification to Economic Integration: Productivity and the Labor Market in Eastern Germany. Brook Pap Econ Act 2001(2):1-92

Chevalier A, Marie O (2017) Economic Uncertainty, Parental Selection, and Children's Educational Outcomes. J Polit Econ 125:393-430

Eberstadt N (1994) Demographic Shocks after Communism: Eastern Germany, 1989-93. Popul Dev Rev 20(1):137-152 
Ehling M (1999) The German Time Use Survey - Methods and Results. In: Merz J,Ehling M (eds) Time Use - Research, data and policy. FFB-Schriftenreihe Band 10, Nomos Verlagsgesellschaft, Baden-Baden, pp 89-106

Ghez GR, Becker GS (1975) The Allocation of Time and Goods over the Life Cycle. National Bureau of Economic Research, New York

Haisken-DeNew JP, Frick JR (2005) Desktop companion to the German Socio-Economic Panel Study (GSOEP), Version 8.0 - Update to Wave 21. German Institute for Economic Research, Berlin

Hall J, Ludwig U (1994) East Germany's Transitional Economy. Challenge 37(5):26-32

Heckman JJ (1979) Sample Selection Bias as a Specification Error. Econometrica 47(1):153-161

Hersch J (2009) Home Production and Wages: Evidence from the American Time Use Survey. Rev Econ Househ 7(2):159-178

Hunt J (2001) Post-Unification Wage Growth in East Germany. Rev Econ Stat 83:190-195

Hunt J (2008) The Economics of German Reunification. In: Durlauf SN, Blume LE (eds) The new palgrave dictionary of economics, 2nd edn. Palgrave Macmillan, Basingstoke

Kawaguchi D, Lee J, Hamermesh DS (2013) A Gift of Time. Labour Econ 24:205-216

Kimmel J, Connelly R (2007) Determinants of Mother's Time Choices in the United States: Caregiving, Leisure, Home Production, and Paid Work. J Hum Resour 42(3):643-681

Konietzka D, Kreyenfeld M (2001) Non-marital births in East Germany after unification. MPIDR Working Paper WP 2001-027. http:/www.demogr.mpg.de/Papers/Working/wp-2001-027.pdf

Kratzer N, Fuchs T, Wagner A, Sauer D (2005) Zeitmuster - Zeitverwendung im Kontext von Erwerbsarbeit und Haushalt. In: Berichterstattung zur sozioökonomischen Entwicklung in Deutschland. VS Verlag für Sozialwissenschaften, Wiesbaden, pp 381-402. https://doi.org/10.1007/978-3-322-80600-0

Krueger AB, Pischke J-S (1995) A Comparative Analysis of East and West German Labor Markets before and after Unification. In: Freeman RB, Katz LF (eds) Differences and changes in wage structures. University of Chicago Press, Chicago, pp 405-446

Lechner, M., Miquel, R., Wunsch, C. (2007). The Curse and Blessing of Training the Unemployed in a Changing Economy: The Case of East Germany After Unification. German Economic Review, 8 (4): 468-509

Marti J, Guthmuller S, Kaufmann C, Boes S (2017). Cultural differences in health behaviors: regression discontinuity evidence from Switzerland. Working Paper, October 2017

Mora R, Reggio I (2015) Didq: A Command for Treatment-Effect Estimation under Alternative Assumption. Stata J 15(3):796-808

Robinson J, Godbey G (1999) Time for Life. Pennsylvania State University Press, University Park

Schulze Buschoff K (1997) Arbeitszeiten - Wunsch und Wirklichkeit in Ost- und Westdeutschland. WZB Discussion Paper, No. FS III 97-410. https://www.econstor.eu/bitstream/10419/50190/1/246100907.pdf

Strawe C (1994) Arbeitszeit, Sozialzeit, Freizeit: Ein Beitrag zur Überwindung der Arbeitslosigkeit. https://www.dreigliederung.de/essays/1994-12-001

Von Hagen J, Strauch R (1999) Tumbling giant: Germany's experience with the Maastricht Fiscal Criteria. ZEI Working Paper

Wang M, Rieger MO, Hens T (2011) How time preferences differ: evidence from 45 countries. Department of Business and Management Science, Norwegian School of Economics (Discussion Papers)

Witte JC, Wagner GG (1995) Declining Fertility in East Germany after Unification: A Demographic Response to Socioeconomic Change. Popul Dev Rev 21:387-397 